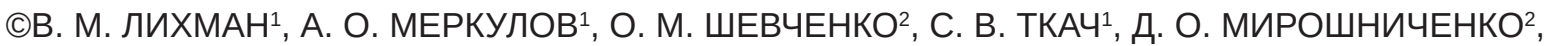
Є. О. БІЛОДІД², Н. В. БАЦМАН ${ }^{2}$, К. М. ЯЦЬКО

Інститут загальної та невідкладної хірургії імені В. Т. Зайцева НАМНУ1ㅡㄴ

Харківський національний медичний університет ${ }^{2}$

\title{
Діагностичні критерії гострого деструктивного панкреатиту
}

\begin{abstract}
Мета роботи: дослідження білків гострої фази у крові хворих на гострий панкреатит різного ступеня тяжкості.
Матеріали і методи. В основу дослідження покладено результати обстеження 88 хворих із гострим панкреатитом різного ступеня тяжкості, які перебували на лікуванні в клініці Інституту загальної та невідкладної хірургії імені В. Т. Зайцева НАМНУ, м. Харків, а також 45 донорів (контрольна група).

Результати досліджень та їх обговорення. Проводили визначення активності сироваткових ензимів у динаміці гострого деструктивного панкреатиту. Верифікацію показників проводили перед операцією й після операційного лікування в динаміці, а також перед повторною операцією і після неї у динаміці. Маркери тканинної деструкції можуть одночасно слугувати індикаторами тяжкості запального процесу в підшлунковій залозі й визначати якість проведеного операційного втручання.

У порядку обговорення та порівняння з роботами інших авторів можна встановити доведену діагностичну цінність феритину та лактоферину як маркерів гострого деструктивного процесу підшлункової залози на підставі достовірного підвищення їх рівня в сироватці крові й ексудатах хворих.

Виявлені зміни концентрації клініко-лабораторних показників альфа-2-макроглобуліну, лактоферину, С-реактивного білка, феритину в сироватці крові корелюють зі ступенем запальних процесів і гнійно-деструктивних змін у підшлунковій залозі.
\end{abstract}

Ключові слова: гострий панкреатит; панкреонекроз; діагностика.

Постановка проблеми і аналіз останніх досліджень та публікацій. На сьогодні частота випадків гострого панкреатиту становить 5-10 \% від загальної кількості хворих хірургічного профілю [1]. На жаль, змінилася лише структура летальності - раніше велику частину смертей спостерігали у ферментативній фазі розвитку панкреонекрозу, зараз пацієнти частіше помирають у пізніх стадіях захворювання внаслідок приєднання інфекції та розвитку панкреатогенного сепсису [2-4].

Поява інноваційних технологій, удосконалення діагностичних методів, можливостей інтенсивної терапії, антибактеріальної профілактики, хірургічних методів лікування із залученням мінііназивної хірургії не вирішує проблему високої загальної летальності при тяжкому гострому панкреатиті на даному етапі [5]. Цей показник впродовж останніх десятиліть зберігається на високому рівні (10-30 \%) та при інфікованих формах гострого панкреатиту досягає майже 85 \% [6, 7]. До традиційних лабораторних критеріїв інфікованого панкреонекрозу можна віднести також лейкоцитоз зі зрушенням лейкоцитарної формули вліво і появою у ній мієлоцитів та метамієлоцитів; збільшення лейкоцитарного індексу інтоксикації (ЛІІ); збільшення ядерного індексу зсуву; зростання глюкози крові; зростання сечовини крові; зростання нейтрофільно-лімфоцитарного коефіцієнта; зменшення кліренсу ендогенного креатиніну; збільшення трансаміназ крові $[8,9]$. Однак відомо, що дані ла- бораторні ознаки не є високоспецифічними, тому у встановленні точного діагнозу можуть тільки зорієнтувати лікаря на виявлення інших, більш точних ознак інфекційного процесу [10]. На сьогодні питома вага помилок діагностики при розвитку гнійних ускладнень панкреонекрозу досягає 40 \%, тому можна зробити висновки про наявність значних труднощів, пов'язаних із ранньою диференційною діагностикою даної форми гострого панкреатиту. Найчастіше ця проблема призводить до затримки верифікації ступеня тяжкості цієї хірургічної патології і, як наслідок, вибору необгрунтованої тактики лікування [11].

Активація панкреатичних ферментів при гострому панкреатиті в осередках ураження і порушення відтоку у протоковій системі сприяють їх потраплянню у кров, головним чином через органний та регіонарний лімфатичний дренаж [6].

Дослідження активності панкреатичних ферментів у крові хворого відіграє найважливішу роль у діагностиці гострого панкреатиту. Екскреційні та тканинні ферменти підшлункової залози з діагностичних позицій розділені на дві групи індикаторні ( $\alpha$-амілаза, трансамідіназа) та патогенетичні (ліпаза, трипсин, еластаза-1) [1].

У діагностичному плані найбільше значення для діагностики гострого панкреатиту мають індикаторні ферменти. Визначення активності $\alpha$-амілази - вельми чутливий і цінний критерій діагностики гострого панкреатиту та контролю за 
ефективністю лікування [10]. Також розглядаючи лабораторну діагностику гострого панкреатиту (ГП), варто згадати і про білки гострої фази (acutephase proteins). Підвищення рівня білків гострої фази при запаленні є компенсаторною реакцією, пов’язаною з властивістю пригнічувати звільнені у процесі деструкції клітини і викликати вторинне ушкодження тканини протеолітичними ферментами, а також пригнічувати автоімунну агресію [4]. Завдяки цьому в організмі обмежується запальний процес та стримується автоагресія $[1,8]$.

У даному дослідженні звернено увагу на таких представників білків гострої фази: С-реактивний білок, лактоферин, феритин, альфа-2макроглобулін.

Мета роботи: дослідження білків гострої фази у крові хворих на гострий панкреатит різного ступеня тяжкості.

Матеріали і методи. В основу дослідження покладено результати обстеження 88 хворих із гострим панкреатитом різного ступеня тяжкості, які перебували на лікуванні в клініці Інституту загальної та невідкладної хірургії імені В. Т. Зайцева НАМНУ, м. Харків, а також 45 донорів (контрольна група).

Дослідження виконані 3 дотриманням основних положень "Правил етичних принципів проведення наукових медичних досліджень за участю людини”, затверджених Гельсінською декларацією (1964-2013рр.), ICH GCP (1996р.), Директиви ЄЕС № 609 (від 24.11.1986 р.), наказів МО3 України № 690 від 23.09.2009 р., № 944 від 14.12.2009 р., № 616 від 03.08.2012 р. Всі учасники були інформовані щодо цілей, організації, методів дослідження та підписали інформовану згоду щодо участі у ньому, і вжиті всі заходи для забезпечення анонімності пацієнтів.

У групі хворих із гострим панкреатитом переважали пацієнти віком від 30 до 55 років. Стерильний панкреонекроз (СП) та інфікований панкреонекроз (ІП) спостерігалися у 62 \% хворих на панкреатит. Набряклий панкреатит діагностували у 38 \% хворих, які отримували консервативне лікування.

При госпіталізації хворим проводили стандартні обстеження: оцінку анамнезу, фізикальних даних, за показаннями проводили рентгенографію грудної та черевної порожнин, УЗД органів черевної порожнини та позаочеревинного простору, ендоскопічне дослідження, МСКТ.

Виконували лабораторні обстеження: загальний аналіз крові, сечі, визначення гематокриту, амілази, ліпази крові, діастази сечі, білірубіну, загального білка, лейкоцитарної формули. Клінічні, лабораторні та інструментальні параметри аналізували при надходженні, до- й після операції у терміни 1, 2, 3, 5-7, 9-12 доба, а також до- й після повторної операції у динаміці в разі її необхідності. Обсяг і тактика хірургічного лікування визначалися відповідно до ступеня тяжкості патологічного процесу. Об’єктом лабораторного дослідження були зразки сироватки крові хворих із гострим панкреатитом, забір біологічного матеріалу проводили під час надходження, до операції, на 1-3 доби, 5-7 доби та на 9-12 доби після операції.

За методамим імуноферментного аналізу (ІФА) та імунодифузійного аналізу (ІДА) всі зразки клінічного матеріалу були протестовані на лактоферин (ЛФ), альфа-2-макроглобулін (МГ), С-реактивний білок (СРБ), феритин за інструкціями фірм-виробників $з$ використанням комерційних тест-систем.

Результати досліджень та їх обговорення. Проводили визначення активності раніше заявлених сироваткових ензимів (СРБ, МГ, ЛФ, феритин) у динаміці гострого деструктивного панкреатиту. Верифікацію показників проводили перед операцією й після операційного лікування в динаміці, а також перед повторною операцією і після неї у динаміці. Результати показників вище перелічених протеїнів у сироватці крові при гострому панкреатиті були оброблені за допомогою статистичних методів та представлені у вигляді середніх значень (табл. 1).

При вивченні сироваткових рівнів заявлених білків у хворих із гострим панкреатитом виявлено такі загальні закономірності: всі ензими, крім альфа-2-макроглобуліну, проявляли підвищені концентрації порівняно 3 контрольною групою донорів. Кожен, без сумніву, відрізнявся своєю динамікою й залежністю від ступеня тяжкості і характеру перебігу запального процесу. При вивченні рівнів СРБ у всіх хворих у передопераційному та ранньому післяопераційному періоді (1-7 доби спостереження) пікові значення (у 10-15 разів вище норми) показників СРБ фіксували у хворих при госпіталізації та у ранньому післяопераційному періоді. Підвищення показників майже вдвічі спостерігали на 1-3 доби після операції. Достовірно підвищений рівень зберігався у пацієнтів із деструктивними формами гострого панкреатиту i до 12 доби. Рівень феритину у сироватці крові хворих із ГП був достовірно підвищеним порівняно 3 контролем $(113 \pm 18,4)$ нг/мл до операції майже у 5 разів. У післяопераційному періоді показники феритину знижувалися, але водночас були достовір- 
Таблиця 1. Динаміка білків гострої фрази у сироватці крові донорів (контроль) та хворих із гострим

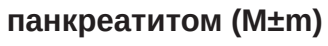

\begin{tabular}{|c|c|c|c|}
\hline Показники & Терміни дослідження & Гострий панкреатит (88) & Контроль (45) \\
\hline СРБ (мг/л) & $\begin{array}{c}\text { До операції (доба) } \\
1-3 \\
5-7 \\
9-12\end{array}$ & $\begin{array}{l}24,3 \pm 5,04^{*} \\
13,6 \pm 6,27^{*} \\
13,1 \pm 5,66^{*} \\
10,9 \pm 3,74^{*}\end{array}$ & $0,8 \pm 0,5$ \\
\hline Феритин (нг/мл) & $\begin{array}{c}\text { До операції (доба) } \\
1-3 \\
5-7 \\
9-12\end{array}$ & $\begin{array}{l}499 \pm 69,0 \\
369 \pm 29,3 \\
239 \pm 28,7 \\
211 \pm 29,5\end{array}$ & $113 \pm 18,4$ \\
\hline ЛФ (нг/мЛ) & $\begin{array}{c}\text { До операції (доба) } \\
1-3 \\
5-7 \\
9-12\end{array}$ & $\begin{array}{l}2899 \pm 302^{*} \\
2689 \pm 235^{*} \\
2299 \pm 205^{*} \\
1497 \pm 220^{*}\end{array}$ & $1048 \pm 48$ \\
\hline МГ (мГ/л) & $\begin{array}{c}\text { До операції (доба) } \\
1-3 \\
5-7 \\
9-12\end{array}$ & $\begin{array}{c}493 \pm 94 * \\
688 \pm 209 * \\
789 \pm 178 \\
1193 \pm 64\end{array}$ & $1029 \pm 51$ \\
\hline
\end{tabular}

Примітка: *-достовірні (від початку р<0,05) відмінності з контрольною групою донорів.

но підвищеними аж до 5-7 доби. На 9-12 доби відбувалося падіння сироваткового рівня феритину та відстежувалася статистично достовірна відмінність даного білка від контрольних цифр. Можна зробити висновок, що пікові рівні сироваткового феритину при тяжких формах гострого панкреатиту діагностуються тільки у передопераційному періоді, а після операційного втручання відбувається повільне, але неухильне зниження середніх показників у всіх пацієнтів. Ми визначили, що у ранньому післяопераційному періоді рівень ЛФ залишався достовірно підвищеним, а у подальшому, аж до 9-12 доби післяопераційного періоду, при динамічному спостереженні спостерігалася тенденція до його зниження у пацієнтів із ГП.

Абсолютно протилежна тенденція відносно вищеописаних ензимів виявлено при вивченні альфа-2-макроглобуліну. Даний білок показав рівні нижче контрольних показників (1029 51$)$ мг/л у момент маніфестації запального процесу, з'являлася тенденція до підвищення у післяопераційному періоді.

Варто зазначити, що лише у тяжких пацієнтів із ускладненим перебігом ГП у передопераційному періоді фіксувалися статистично значущі від-

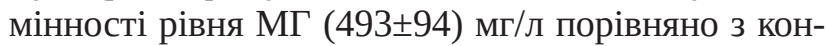
трольними цифрами. При деструктивних формах ГП біосинтез МГ у кров максимально пригнічується. У ранньому післяопераційному періоді рівень
МГ у хворих ГП достовірно нижче норми, а згодом показник поступово підвищується і фіксується приблизно на одному рівні з контрольними цифрами. Таким чином, маркери тканинної деструкції СРБ, феритин, ЛФ і МГ можуть одночасно слугувати індикаторами тяжкості запального процесу в підшлунковій залозі й визначати якість проведеного операційного втручання. Аналіз динаміки середніх показників у сироватці крові білків-реактантів у взаємозв'язку зі ступенем тяжкості процесу при ГП був досить інформативним і показав деякі особливості. У випадку з СРБ - високодостовірні відмінності з контрольною групою донорів зберігалися і при набряковій формі панкреатиту, і у тяжких хворих з інфікованим панкреонекрозом (ІП). У групі хворих із стерильним панкреонекрозом (СП) статистично значущі відмінності від контрольних цифр виявляли не в усі терміни спостереження (табл. 2).

На 5-7 та 9-12 доби післяопераційного періоду рівні СРБ були вищими від донорських значень, але відмінності були статистично недостовірними. Набряковій формі та СП відповідали дуже високі рівні сироваткового СРБ при надходженні (практично у 24 рази більше контролю: відповідно, 23,8 $\pm 5,99$ і 26,8 $\pm 11,69$ мг/л), але на наступну добу спостерігалася тенденція до досить швидкого зниження його сироваткових концентрацій СРБ. 
Таблиця 2. Динаміка білків гострої фрази у сироватці крові донорів (контроль) та хворих із стерильним панкреонекрозом (M $\pm \mathrm{m})$

\begin{tabular}{|c|c|c|c|c|c|}
\hline Показники & Терміни (діб) & $\begin{array}{c}\text { C-реактивний } \\
\text { білок (мг/л) }\end{array}$ & $\begin{array}{c}\text { Макроглобулін } \\
\text { (мг/л) }\end{array}$ & $\begin{array}{c}\text { Феритин } \\
\text { (нг/мл) }\end{array}$ & $\begin{array}{c}\text { Лактоферин } \\
\text { (нг/мл) }\end{array}$ \\
\hline 1-ша група (ГП) & $\begin{array}{c}\text { До операції } \\
1-3 \\
5-7 \\
9-12\end{array}$ & $\begin{array}{c}- \\
23,8 \pm 5,99 * \\
16,3 \pm 6,01 * \\
8,7 \pm 3,11^{*}\end{array}$ & $\begin{array}{c}- \\
766 \pm 173 \\
912 \pm 173 \\
1197 \pm 188\end{array}$ & $\begin{array}{c}- \\
272 \pm 67,0 \\
193 \pm 37,5 \\
157 \pm 31,9\end{array}$ & $\begin{array}{c}- \\
1383 \pm 248 * \\
1012 \pm 173 \\
817 \pm 222\end{array}$ \\
\hline 2-га група (СП) & $\begin{array}{c}\text { До операції } \\
1-3 \\
5-7 \\
9-12\end{array}$ & $\begin{array}{c}26,8 \pm 11,69 * \\
11,8 \pm 4,77^{*} \\
8,4 \pm 4,33 \\
4,9 \pm 2,36\end{array}$ & $\begin{array}{c}590 \pm 206^{*} \\
788 \pm 289 \\
884 \pm 160 \\
1098 \pm 197\end{array}$ & $\begin{array}{c}414 \pm 74,8^{*} \\
339 \pm 29,3^{*} \\
182 \pm 18,4^{*} \\
181 \pm 41,7\end{array}$ & $\begin{array}{l}2680 \pm 229 * \\
3080 \pm 287 * \\
2570 \pm 183^{*} \\
1534 \pm 208 *\end{array}$ \\
\hline $\begin{array}{l}\text { 3-тя група } \\
\text { (IП) }\end{array}$ & $\begin{array}{c}\text { До операції } \\
1-3 \\
5-7 \\
9-12\end{array}$ & $\begin{array}{l}13,7 \pm 4,76^{*} \\
11,6 \pm 5,07^{*} \\
17,7 \pm 5,87^{*} \\
20,8 \pm 6,67^{*}\end{array}$ & $\begin{array}{c}429 \pm 203 * \\
599 \pm 230 * \\
690 \pm 186 \\
788 \pm 190\end{array}$ & $\begin{array}{c}534 \pm 206,2^{*} \\
412 \pm 69,3^{*} \\
308 \pm 77,3^{*} \\
209 \pm 42,8\end{array}$ & $\begin{array}{c}3296 \pm 387 * \\
2007 \pm 387 * \\
1677 \pm 189 * \\
1134 \pm 327\end{array}$ \\
\hline Контроль & - & $0,8 \pm 0,4$ & $1019 \pm 59$ & $109 \pm 26,3$ & $1033 \pm 76$ \\
\hline
\end{tabular}

Примітка: * - достовірні (від початку р<0,05) відмінності з контрольною групою донорів.

При ІП середні сироваткові показники СРБ у хворих 3 підгрупи у передопераційному і ранньому післяопераційному (1-3 доби) періоді були достовірно вищими від норми тільки у 13 разів

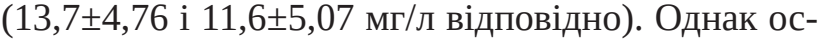
новна тенденція експресії у кров СРБ у хворих 3 ІП різко відрізнялася від 1 та 2 підгруп хворих 3 набряковою формою та СП. Повторне наростання середніх рівнів СРБ до 17,7 $\pm 5,87$ фіксували на 5-7 доби, до 20,8 $\pm 6,67$ мг/л - на 9-12 доби післяопераційного періоду. Дане спостереження дає можливість припустити, що повторний підйом середніх значень СРБ при ІП пов’язаний із загрозою розвитку ускладнень та вкрай несприятливим перебігом післяопераційного періоду, що передбачає несприятливий результат захворювання.

Залізовміщувальний білок феритин у ході вивчення його середніх сироваткових рівнів у хворих із ГП у взаємозв'язку зі ступенем тяжкості патологічного процесу показав достовірне підвищення показників у підгрупах панкреонекрозу в передопераційному та післяопераційному періодах аж до 5-7 доби. У пацієнтів із набряковою формою, які лікувалися консервативно, не було виявлено статистично значущих підйомів концентрацій феритину у всі терміни клінічного спостереження. При цьому у всіх трьох підгрупах фіксували пікові показники сироваткового феритину в передопераційному періоді або на початку консервативної терапії. Незалежно від результату захворювання також простежувалася вже передбачувана тенден- ція до зниження показників феритину у всіх підгрупах у наступні дні спостереження. Встановлено, що в підгрупах хворих відповідно до ступеня тяжкості середні рівні сироваткового феритину на будь-якому терміні обстеження виявляли чітку тенденцію до підвищення експресії даного ензиму в крові.

Таким чином, накопичення феритину в сироватці крові у пацієнтів з ОП залежить від ступеня вираження процесів тканинної деструкції: чим тяжчий перебіг захворювання, тим інтенсивніше в післяопераційному періоді перебігає накопичення в крові даного білка.

Взаємно зворотні процеси (поступове скорочення запасів феритину та зменшення площі осередку деструкції в ході репарації тканин підшлункової залози в післяопераційному періоді) стимулює зниження концентрації даного ензиму в сироватці крові. Різниця показників за феритином у разі панкреаонекрозу дає можливість його застосування, як і СРБ як показника загрози розвитку різних післяопераційних ускладнень, а також маркера для визначення приблизного обсягу некротичного ураження підшлункової залози та індикатора якості проведеного операційного втручання і приєднання інфекційного процесу.

Білок ЛФ у взаємозв’язку з тяжкістю патологічного процесу у ПЗ виявився навіть більш високочутливим, ніж феритин. У загальній групі пацієнтів із гострим панкреатитом показник ЛФ тримався на достовірно підвищеному рівні аж до 
9-12 доби післяопераційного періоду. Статистично значущі показники ЛФ у підгрупах фіксували у пацієнтів з ІП у весь період спостереження, крім 9-12 доби. При стерильній формі панкреонекрозу високі рівні ЛФ були отримані в усі терміни дослідження. При набряковій формі достовірне підвищення рівня сироваткового ЛФ фіксували тільки на 1-3 доби з моменту надходження пацієнтів у стаціонар і початку консервативного лікування. Особливістю експресії ЛФ у кров при порівняльному аналізі двох підгруп панкреонекрозу стало спостереження при стерильній формі специфічної відстроченої динаміки регресії концентрації ЛФ, пік якої припадав на ранній післяопераційний період (1-3 доби після операції).

Таким чином, у підгрупах хворих із гострим панкреатитом відповідно до ступеня тяжкості процесу в усі терміни дослідження в післяопераційному періоді середні показники сироваткового ЛФ демонструють тенденцію до регресії рівнів. Однак на момент госпіталізації в стаціонар при інфікованій формі концентрації ЛФ були вищими, ніж при стерильній.

Білок МГ активно проявляв протилежні властивості при гострому панкреатиті відносно решти білків-реактантів. Достовірно низькі показники щодо норми при ГП фіксували в ранньому післяопераційному періоді (1-3 доби після лапаротомії). Пікові негативні показники середніх рівнів МГ встановили в сироватці крові у хворих з ІП на момент госпіталізації (44,9 \% від норми). Вищеописані факти, ймовірно, свідчать про особливу активність МГ у системних процесах інгібування протеолітичних ферментів при ГП. Також достовірно низькі рівні МГ у передопераційному періоді спостерігають при обох формах деструктивного

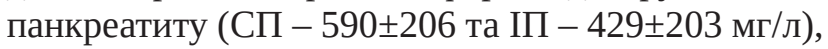
а в ранньому післяопераційному періоді - тільки у хворих зі стерильною формою (788 289 мг / л).

Дослідження показників МГ у пацієнтів з набряковою формою ГП, які отримували консервативне лікування, на всіх етапах спостереження відмінності середніх величин порівняно 3 контролем були статистично недостовірними. При проведенні детального аналізу середніх сироваткових рівнів МГ у пацієнтів із ГП було з'ясовано, що на всіх етапах тестування концентрації даного ензиму виявляють чітку тенденцію до зниження зі збільшенням ступеня тяжкості процесу.

При ГП низькі показники сироваткового МГ у передопераційний період (нижче 550 мг/л) та від- сутність їх істотного зростання у післяопераційний період із високим ступенем ймовірності може свідчити про несприятливий прогноз результату захворювання. Повторне зменшення показників МГ є індикатором розвитку ускладнень та приєднання інфекційного процесу.

У порядку обговорення та порівняння з роботами інших авторів можна вказати на доведену діагностичну цінність феритину і лактоферину як маркерів гострого деструктивного процесу підшлункової залози на підставі достовірного підвищення їх рівня в сироватці крові й ексудатах хворих [12]. Показано, що феропротеїни $€$ надійними маркерами запального процесу поряд з іншими, в тому числі класичними, білками гострої фази. При цьому їх виявлення відрізняється достовірністю у діагностиці не тільки явних, але i латентних деструктивних станів.

Висновки. Виявлені зміни концентрації клініко-лабораторних показників альфа-2-макроглобуліну, лактоферину, С-реактивного білка, феритину у сироватці крові корелюють зі ступенем запальних процесів та гнійно-деструктивних змін у підшлунковій залозі. Граничними рівнями, що свідчать про можливе інфікування зон деструкції, можна вважати: СРБ $\geq 34$ мг/л, МГ $\leq 645$ мг/л, Ф $\geq 595$ нг/мл, ЛФ $\geq 2490$ нг/мл. У разі виявлення рівнів даних показників вище порогового значення діагностується інфікований панкреонекроз, нижче порогових значень правомірний діагноз “стерильний панкреонекроз”. Тест на дані білки можна застосовувати як простий, економічний та високочутливий метод для ранньої діагностики інфікованого панкреонекрозу.

Перспективи подальших досліджень. Подальші дослідження будуть направлені на розробку алгоритму лікування хворих із деструктивним панкреатитом залежно від діагностичних і клініко-лабораторних критеріїв.

Зв'язок роботи 3 науковими програмами, планами, темами. Роботу виконано відповідно до НДР ДУ “ІЗНХ імені В. Т. Зайцева НАМН України” у відділенні хірургічних інфекцій та $€$ фрагментом науково-дослідної роботи “Профілактика та хірургічне лікування арозивних кровотеч у хворих з панкреонекрозом при застосуванні мініінвазивних хірургічних втручань”, номер держ. реєстрації 0118U006666П.0119. 


\section{ОРИГІНАЛЬНІ ДОСЛІДЖЕННЯ}

\section{СПИСОК ЛІТЕРАТУРИ}

1. Дарвин В. В. Тяжелый острый панкреатит / Основные факторы риска неблагоприятных исходов / В. В. Дарвин, Е. А. Краснов, С. В. Онищенко // Материалы XXIV Международного конгресса Ассоциации гепатопанкреатобилиарных хирургов стран СНГ. - СПб., 2017. - С. 61-62.

2. Bollen T. L. Acute pancreatitis: international classification and nomenclature / T. L. Bollen // Clin Radiol. - 2016. - 71 (2). P. 121-33. PMID: 26602933. DOI: 10.1016/j.crad.2015.09.013. 3. Greenberg J. A. Clinical practice guideline: management of acute pancreatitis/ J. A. Greenberg, J. Hsu, M. Bawazeer // Can. J. Surg. - 2016. - 59 (2). P. 128-40. PMID: 27007094. PMCID: PMC4814287. DOI: 10.1503/cjs.015015.

4. Comparison of laparoscopy and open surgery in treating severe acute pancreatitis and its relative aftercare / J. Zhang, M. X. Jiang, Y. Zheng [et al.] // J. Biol. Regul. Homeost. Agents. - 2016. - Vol. 30 (1). P. 189-95. PMID: 27049091

5. Бахтин В. А. Опыт лечения инфицированного панкреонекроза / В. А. Бахтин, В. М. Русинов, В. А. Янченко // Материалы V Межрегион. научно-практической конференции. Актуальные вопросы абдоминальной хирургии. Томск, 2016. - C. $12-24$.

6. Авижец Ю. Н. Распространенный ферментативный парапанкреатит как компонент панкреонекроза по данным аутопсии / Ю. Н. Авижец, В. М. Майоров, З. А. Дундаров // Материалы XXIV Международного конгресса Ассоциации гепатопанкреатобилиарных хирургов стран СНГ. - СПб. -
2017. - C. 54-55.

7. Werge M. Gluud Infection increases mortality in necrotizing pancreatitis: A systematic review and meta-analysis / M. Werge, S. Novovic, P. Schmidt // Pancreatology. - 2016. - Vol. 16 (5). P. 698-707. PMID: 27449605. DOI: 10.1016/j.pan.2016.07.004

8. Forsmark C. E. Predicting the prognosis of acute pancreatitis / C. E. Forsmark, D. Yadav // Ann. Intern. Med. - 2016. - Vol. 165 (7). - P. 523-524. PMID: 27454430. PMCID: PMC6042968. DOI: $10.7326 / \mathrm{M} 16-1581$

9. Maheshwari R. Severe acute pancreatitis and necrotizing pancreatitis / R. Maheshwari, R. M. Subramanian // Crit. Care Clin. - 2016. - Vol. 32 (2). - P. 279-290. PMID: 27016168. DOI: 10.1016/j.ссс.2015.12.006

10. Винник Ю. С. Оценка тяжести панкреатогенного иммунодефицита в условиях хирургического стационара / Ю. С. Винник, С. С. Дунаевская // Материалы XXIV Международного конгресса Ассоциации гепатопанкреатобилиарных хирургов стран СНГ. - СПб. - 2017. - С. 57-58.

11. Kwong W. T. Predictors and outcomes of moderately severe acute pancreatitis - Evidence to reclassify / W. T. Kwong, F. Ondrejková, S. S. Vege // Pancreatology. - 2016. - Vol. 16 (6). - P. 940-945. PMID: 27618656. DOI: 10.1016/j.pan.2016.08.001 12. Рамазанов М. В. Сравнительное биохимическое и иммунохимическое изучение тканевых и сывороточных железосодержащих белков / М. В. Рамазанов // Абстр.PhD. (Биоло.). - Казань, 2012. 145 с.

\section{REFERENCES}

1. Darvin, V.V., Krasnov, E.A., \& Onishchenko, S.V. (2017). Tyazhelyy ostryy pankreatit: Osnovnye faktory riska neblagopriyatnyh iskhodov [Heavy acute pancreatitis: the main risk factors of adverse outcomes]. Materialy XXIV Mezhdunarodnogo kongressa Assotsiatsii gepatopankreatobiliarnyh hirurgov stran SNG - Materials of the XXIV International Congress of the Association of Hepatopancreatobiliary Surgeons of the CIS countries. Saint-Petersburg [in Russian].

2. Bollen, T.L. (2016). Acute pancreatitis: international classification and nomenclature. Clin. Radiol., 71 (2), 121-133. PMID: 26602933. DOI: 10.1016/j.crad.2015.09.013.

3. Greenberg, J.A., Hsu, J., \& Bawazeer, M. (2016). Clinical practice guideline: management of acute pancreatitis. Can. J. Surg., 59 (2), 128-140. PMID: 27007094. PMCID: PMC4814287. DOI: $10.1503 /$ cjs.015015.

4. Zhang, J., Jiang, M.X., Zheng Y., Shu, M, Sun, SB. (2016). Comparison of laparoscopy and open surgery in treating severe acute pancreatitis and its relative aftercare. J. Biol. Regul. Homeost Agents. 30 (1), 189-95. PMID: 27049091

5. Bahtin, V.A., Rusinov, V.M., \& Yanchenko, V.A. (2016). Opyt lecheniya infitsirovannogo pankreonekroza [Experience in treating infected pancreonecrosis]. Materialy V Mezhregion. nauchno-prakticheskoy konferentsii. Aktualnye voprosy abdominalnoy khirurgii - Materials of the VInterregion. Scientific and Practical Conference. Topical issues of abdominal surgery, Tomsk [in Russian].

6. Avizhec, Yu.N., Mayorov, V.M., \& Dundarov, Z.A. (2017). Rasprostranennyy fermentativnyy parapankreatit kak morfologicheskiy komponent pankreonekroza po dannym autopsii [Common enzymatic parapancreatitis as a morphological component of pancreatic proceedings according to autopsy]. Materialy XXIV

Mezhdunarodnogo Kongressa Assotsiatsii gepatopankreatobiliarnyh hirurgov stran SNG - Materials of the XXIV International Congress of the Association of Hepatopancreatobiliary Surgeons of the CIS countries. Saint-Petersburg [in Russian].

7. Werge, M., Novovic, S., \& Schmidt, P. (2016). Gluud Infection increases mortality in necrotizing pancreatitis: A systematic review and meta-analysis. Pancreatology, 16 (5), 698-707. PMID: 27449605. DOI: 10.1016/j.pan.2016.07.004

8. Forsmark, C.E., \& Yadav, D. (2016). Predicting the prognosis of acute pancreatitis. Ann Intern. Med., 165 (7), 523-524. PMID: 27454430. PMCID: PMC6042968. DOI: 10.7326/M16-1581

9. Maheshwari, R., \& Subramanian, R.M. (2016). Severe acute pancreatitis and necrotizing pancreatitis. Crit. Care Clin. 32 (2), 279-290. PMID: 27016168. DOI: 10.1016/j.ccc.2015.12.006 10. Vinnik, Yu.S., \& Dunaevskaya, S.S. (2017). Otsenka tyazhesti pankreatogennogo immunodefitsita $\mathrm{v}$ usloviyakh khirurgicheskogo statsionara [Estimation of the gravity of pancreatogenic immunodeficiency in a surgical hospital]. Materialy XXIV Mezhdunarodnogo Kongressa Associatsii gepatopankreatobiliarnyh hirurgov stran SNG - Materials of the XXIV International Congress of the Association of Hepatopancreatobiliary Surgeons of the CIS countries. Saint-Petersburg [in Russian].

11. Kwong, W.T., Ondrejková, F., \& Vege, S.S. (2016). Predictors and outcomes of moderately severe acute pancreatitis - Evidence to reclassify. Pancreatology, 16 (6), 940-945. PMID: 27618656. DOI: 10.1016/j.pan.2016.08.001

12. Ramazanov, M.V. (2012). Sravnitelnoe biohimicheskoe i immunohimicheskoe izuchenie tkanevyh i syvorotochnyh zhelezosoderzhashchih belkov [Comparative biochemical and immunochemical study of fabric and serum iron-containing proteins]. Abstr. PhDr. (Biol.). Kazan [in Russian].

Отримано 01.07.2021 
V. M. LIKHMAN ${ }^{1}$, A. O. MERKULOV ${ }^{1}$, O. M. SHEVCHENKO ${ }^{2}$, S. V. TKACH ${ }^{1}$, D. O. MIROSHNICHENKO ${ }^{2}$, E. O. BELODED ${ }^{2}$, N. V. BATSMAN ${ }^{2}$, K. M. YATSKO ${ }^{1}$

V. T. Zaytsev Institute of General and Urgent Surgery, National Academy of Medical Sciences of Ukraine ${ }^{1}$ Kharkiv National Medical University ${ }^{2}$

\section{DIAGNOSTIC CRITERIA OF ACUTE DESTRUCTIVE PANCREATITIS}

The aim of the work: to study the proteins of the acute phase in the blood of patients with acute pancreatitis of varying severity. Materials and Methods. The study is based on the results of examination of 88 patients with acute pancreatitis of varying severity who were treated at the Institute of the General and Urgent Surgery named after V. T. Zaytsev, Academy of Medical Sciences of Ukraine, Kharkiv, as well as 45 donors (control group).

Results and Discussion. The determination of the activity of serum enzymes in the dynamics of acute destructive pancreatitis was carried out. The parameters were verified before the operation and after the operative treatment in dynamics, as well as before and after the second operation in the dynamics. Markers of tissue destruction can simultaneously serve as indicators of the severity of the inflammatory process in the pancreas and determine the quality of the performed surgical intervention. The diagnostic value of ferritin and lactofferin as markers of an acute destructive process was proved on the basis of a significant increase in their level in blood serum and exudates of patients. It was shown that ferroproteins are reliable markers of the inflammatory process, among others, including classical acute phase proteins. At the same time, their identification is distinguished by its explicitness in the diagnosis of not only latent destructive states.

The detected changes in the concentration of clinical and laboratory parameters of alpha-2-macroglobulin, lactoferrin, C-reactive protein, ferritin in the blood serum correlate with the degree of the inflammatory process and purulent-destructive changes in the pancreas.

Key words: acute pancreatitis; pancreatic necrosis; diagnostics. 